\title{
PENGARUH METODE THINK, PAIR, AND SHARE DAN STRUKTUR KALIMAT TERHADAP KETERAMPILAN BERBICARA BAHASA INDONESIA
}

\author{
Sigit Widiyarto \\ Program Studi Pendidikan Ekonomi \\ Fakultas Ilmu Pendidikan dan Pengetahuan Sosial \\ Universitas Indraprasta PGRI
}

\begin{abstract}
Abstrak
Tujuan penelitian ini adalah untuk mengetahui pengaruh metode think pair and share dan struktur kalimat terhadap keterampilan berbicara Bahasa Indonesia. Metode penelitian ini menggunakan metode eksperimen dengan analisis dua jalur (Anova). Data dan informasi di lapangan memakai hasil tes. Sampel diambil pada kelas VII SMPI Azzuhriyah Jatiasih Bekasi. Jumlah siswa pada kelas kontrol dan eksperimen sebanyak 60 siswa. Berdasarkan analisis data yang dihitung dengan memakai SPSS 22 dapat disimpulkan: 1) Terdapat pengaruh signifikan metode think, pair, and share (TPS) terhadap keterampilan berbicara Bahasa Indonesia. 2) Tidak terdapat pengaruh Metode TPS dan struktur kalimat secara bersama-sama terhadap keterampilan berbicara Bahasa Indonesia. 3) Terdapat Pengaruh Struktur Kalimat terhadap Keterampilan berbicara Bahasa Indonesia.
\end{abstract}

Kata Kunci : metode TPS, struktur kalimat dan keterampilan berbicara

\section{THE EFFECT OF THINK, PAIR AND SHARE METHOD AND SENTENCE STRUCTURE TOWARDS SPEAKING SKILL IN BAHASA INDONESIA}

\begin{abstract}
The aim of this research is to know the effect of think,pair and share method and sentence structure towards speaking skill in Bahasa Indonesia.The research method used is experiment which is done of two ways of Anova table analysis.Data collected conducted by giving the test.The sample was taken at SMPI Azzuhriyah VII Class Jatiasih Bekasi.The number of student at control and experiment class are 60 students. According to the data analysis that calculated by SPSS 22, the conclusion draws: 1) There is a significant effect of think, pair, and share method towards speaking skill in Bahasa Indonesia. 2) There is no effect of think,pair and share and sentence structure together towards speaking skill in Bahasa Indonesia. 3) There is an effect of sentence structure method towards speaking skill in Bahasa Indonesia.
\end{abstract}

Key words : TPS method, sentence structure and speaking skill

\section{PENDAHULUAN}

Bahasa adalah alat komunikasi yang penting dalam kehidupan manusia. Hal ini disebabkan bahasa adalah media komunikasi antar anggota masyarakat yang dapat menyalurkan segala pe- rasaan, ide, imajinasi dan juga kemampuan intelektual. Bahasa memiliki peran sentral dalam perkembangan intelektual, sosial, dan emosional peserta didik. Pembelajaran bahasa membantu peserta didik mengenali dirinya, budaya-nya dan budaya orang lain, mengemuka-kan gagasan dan 
perasaan, berpartisipasi dalam masyarakat yang menggunakan bahasa tersebut, menemukan serta menggunakan kemampuan analitis dan imajinatif yang ada dalam dirinya.

Belajar bahasa dapat dilakukan secara alamiah dan dapat dilakukan melalui jalur pendidikan. Pembelajaran bahasa Indonesia selama ini kurang melatih anak dalam keterampilan menggunakan bahasa untuk berkomunikasi. Siswa lebih banyak diberi pengetahuan dan aturan-aturan tata bahasa tanpa pernah tahu bagaimana mengaitkannya dalam latihan-latihan menulis dan berbicara. Siswa lebih banyak diberi bekal pengetahuan bahasa daripada dilatih menggunakan bahasa.

Dalam belajar bahasa, ada empat aspek keterampilan berbahasa yang harus dipelajari, yaitu keterampilan membaca, keterampilan menulis, keterampilan menyimak, dan keterampilan berbicara. Namun, dalam praktiknya teori-teori kebahasaan lebih banyak dipelajari daripada keterampilan berbahasa.

Padahal, teori-teori kebahasaan digunakan untuk menunjang keterampilan berbahasa baik yang disampaikan secara tulisan maupun secara lisan.

Keempat aspek keterampilan berbahasa tersebut dapat dibagi menjadi dua bagian, yaitu keterampilan reseptif dan keterampilan produktif. Keterampilan reseptif meliputi keterampilan menyimak dan membaca. Dikatakan keterampilan reseptif karena kedua keterampilan tersebut bersifat menerima atau mendapatkan. Artinya, melalui kedua keterampilan ini kita dapat memperoleh segala informasi atau memperoleh wawasan pengetahuan yang lebih luas dan dapat meningkatkan kemampuan intelektual. Keterampilan produktif meliputi keterampilan menulis dan berbicara.
Keterampilan berbicara tidak datang begitu saja, tetapi perlu dilatih secara berkala agar berkembang dengan maksimal. Menurut Henry Guntur Tarigan (2008: 1), keterampilan hanya dapat diperoleh dan dikuasai dengan jalan praktik dan banyak latihan. Kemampuan berbicara ini dilatih dengan tujuan untuk mempermudah memahami maksud yang disampaikan oleh orang lain dalam berkomunikasi. Melatih keterampilan berbicara dimulai sejak dini di lingkungan sekolah tempat dimana siswa belajar. Dalam proses belajar bahasa di sekolah, anak-anak mengembangkan kemampuan secara vertikal dan horizontal (Ahmad Rofie uddin \& Darmiyati Zuhdi, 1998/1999: 11). Kemampuan berbicara tidak diperoleh dengan sendirinya. Kemampuan ini dikembangkan lewat jalur sekolah, melalui program yang direncakan secara khusus dan latihanlatihan (Mudini Salamat Purba, 2009: 1). Keterampilan berbicara jika dikembangkan secara berkala makin lama semakin sempurna dalam arti strukturnya menjadi benar, pilihan katanya semakin tepat, kalimatkalimatnya semakin bervariasi, dan sebagainya. Pencapaian tujuan tersebut, peran guru sangat dibutuhkan. Dalam proses belajar mengajar, guru memegang peranan penting dan tidak dapat digantikan oleh benda apapun. Kelangsungan proses belajar mengajar sangat erat hubungan/kaitannya metode pembelajaran yang digunakan guru.

\section{TINJAUAN PUSTAKA}

\section{Pengertian Metode Pembelajaran Think, Pair, and Share}

Menurut Trianto (2007:61) ThinkPair-Share merupakan jenis cooperative learning yang dirancang untuk mempengaruhi pola interaksi siswa. Menurut Arends (dalam Trianto 2007:61) menyatakan bahwa Think- 
Pair-Share merupakan suatu cara yang efektif untuk membuat variasi suasana pola diskusi kelas.

Think-Pair-Share dimaksudkan sebagai alternatif terhadap metode tradisional yang diterapkan di kelas, seperti ceramah, tanya jawab satu arah, yaitu guru terhadap siswa merupakan suatu cara yang efektif untuk mengganti suasana pola diskusi kelas. (Thobroni dan Mustofa, 2011:297) Sedangkan Think-Pair-Share yang dikembangkan oleh Frank Lyman, dkk dari Universitas Maryland pada tahun 1985.

Think-Pair-Share memberikan kepada para siswa waktu untuk berpikir dan merespon serta saling bantu satu sama lain. Sebagai contoh, seorang guru baru saja menyelesaikan suatu sajian pendek atau para siswa telah selesai membaca suatu tugas. Selanjutnya guru meminta kepada para siswa untuk menyadari secara serius mengenai apa yang telah dijelaskan oleh guru atau apa yang telah dibaca.

Model pembelajaran Think-PairShare adalah salah satu model pembelajaran yang memberi kesempatan kepada setiap siswa untuk menunjukkan partisipasi kepada orang lain.Tahap utama dalam pembelajaran Think-Pair-Share menurut Trianto (2007: 61-62) adalah sebagai berikut:

Langkah 1 : Think (berpikir)

Guru mengajukan suatu pertanyaan atau masalah yang dikaitkan dengan pelajaran, dan meminta siswa menggunakan waktu beberapa menit untuk berpikir sendiri jawaban atau masalah. Siswa membutuhkan penjelasan bahwa berbicara atau mengerjakan bukan bagian berpikir Langkah 2 : Pair (berpasangan)

Guru meminta siswa berpasangan dengan siswa lain untuk mendiskusikan apa yang telah mereka peroleh. Interaksi selama waktu yang disediakan dapat menyatukan gagasan apabila suatu masalah khusus yang diidentifikasi. Biasanya guru memberi waktu 4-5 menit untuk berpasangan.

Langkah 3: Share (berbagi)

Guru meminta pasangan-pasangan untuk berbagi dengan keseluruhan kelas yang telah mereka bicarakan. hal ini efektif untuk berkeliling ruangan dari pasangan ke pasangan dan melanjutkan sampai sekitar sebagian pasangan mendapat kesempatan untuk melaporkan Arends (1997) disadur Tjokrodiharjo, 2003 (dalam Trianto, 2007: 62).

Kegiatan "berpikir-berpasanganberbagi" dalam model Think-Pair-Share memberikan keuntungan. Siswa secara individu dapat mengembangkan pemikirannya masing-masing karena adanya waktu berpikir (think time) sehingga kualitas jawaban juga dapat meningkat. siswa harus saling melaporkan hasil pemikiran masingmasing dan berdiskusi dengan pasangannya (Pair), kemudian pasangan-pasangan tersebut harus berbagi dengan seluruh kelas (Share). Jumlah anggota kelompok yang kecil mendorong setiap anggota untuk terlibat secara aktif, sehingga siswa jarang atau bahkan tidak pernah berbicara di depan kelas paling tidak memberikan ide atau jawaban karena pasangannya.

Kelebihan model pembelajaran Think-Pair-Share menurut Assyafi'i (2009) yaitu:

1. Memberi siswa waktu lebih banyak untuk berpikir, menjawab, dan saling membantu satu sama lain.

2. Lebih banyak kesempatan untuk konstribusi masing-masing anggota kelompok.

3. Interaksi lebih mudah.

4. Lebih mudah dan cepat membentuk kelompoknya.

5. Seorang siswa juga dapat belajar dari siswa lain serta saling menyampaikan idenya untuk 
didiskusikan sebelum disampaikan di depan kelas.

6. Dapat memperbaiki rasa percaya diri dan semua siswa diberi kesempatan untuk berpartisipasi dalam kelas.

7. Siswa dapat mengembangkan keterampilan berpikir dan

8. Menjawab dalam komunikasi antara satu dengan yang lain, serta bekerja saling membantu dalam kelompok kecil.

9. Siswa akan terlatih menerapkan konsep karena bertukar pendapat dan pemikiran dengan temannya untuk mendapatkan kesepakatan dalam memecahkan masalah.

10. Siswa lebih aktif dalam pembelajaran karena menyelesaikan tugasnya dalam kelompok, dimana tiap kelompok hanya terdiri dari 2 orang.

Kekurangan model pembelajaran Think-Pair-Share menurut Assyafi'I (2009) yaitu:

1. Lebih sedikit ide yang muncul.

2. Jika ada perselisihan dalam kelompok tidak ada penengah.

3. Menggantungkan pada pasangan.

4. Jumlah siswa yang ganjil berdampak pada saat pembentukan kelompok, karena ada satu siswa tidak mempunyai pasangan.

5. Jumlah kelompok yang terbentuk banyak.

Solusi untuk kekurangan dari model pembelajaran Think-Pair-Share ini adalah: (a) Guru memonitor terus kinerja siswa; (b) Pembagian pasangan kelompok dengan teman sebangku, hal ini dilakukan untuk meminimalisir terjadinya perselisihan dalam kelompok; (c) Semua siswa harus aktif dalam kelompoknya; (d) Jumlah siswa di kelas harus genap dalam penggunaan model pembelajaran Think-Pair-Share agar setiap kelompok ada pasangannya. (e) Guru aktif dalam membimbing kelompok.

\section{Berbicara}

Berbicara pada hakikatnya merupakan suatu proses komunikasi yang dalam proses itu terjadi pemindahan pesan dari satu pihak (komunikator) ke pihak lain (komunikan). Pesan yang akan disampaikan kepada komunikan lebih dahulu diubah ke simbol-simbol yang dipahami oleh kedua belah pihak (Abd. Gofur dalam Kundharu Saddhono \& Slamet, 2012: 6). Menurut Henry Guntur Tarigan (2008: 16) berbicara adalah kemampuan mengucapkan bunyi-bunyi artikulasi atau kata-kata untuk mengekspresikan, menyatakan atau menyampaikan pikiran, gagasan, dan perasaan. Berbicara juga didefinisikan sebagai suatu alat untuk mengkomunikasikan gagasan-gagasan yang disusun serta dikembangkan sesuai dengan kebutuhan sang pendengar dan penyimak.

Djago Tarigan (1990) dalam Kundharu Saddhono \& Slamet (2012: 34) menyatakan bahwa berbicara adalah keterampilan menyampaikan pesan melalui lisan. Kundharu Saddhono \& Slamet (2012: 34), mengungkapkan bahwa berbicara secara umum dapat diartikan suatu penyampaian maksud bisa berupa gagasan, pikiran, isi hati seseorang kepada orang lain. Brown (2001) dalam Kundharu Saddhono \& Slamet (2012: 57), mengungkapkan bahwa berbicara sebagai salah satu aspek kemampuan berbahasa yang berfungsi untuk menyampaikan informasi secara lisan. Pendapat itu juga dikuatkan oleh pendapat yang diungkapkan oleh Lee (2009) dalam Kundharu Saddhono \& Slamet (2012: 58), menyatakan bahwa berbicara adalah suatu peristiwa penyampaian maksud (ide, pikiran, isi hati) seseorang 
kepada orang lain dengan menggunakan bahasa lisan sehingga maksud tersebut dipahami orang lain. Pada hakikatnya berbicara merupakan ungkapan pikiran dan perasaan seseorang dalam bentuk bunyi-bunyi bahasa (Solchan, dkk. 2008: 1.31).

Berdasarkan sejumlah pengertian di atas, disimpulkan berbicara adalah suatu kegiatan kemampuan berbahasa untuk menyampaikan sebuah ide, gagasan, penadapat, pikiran, dan isi hati kepada orang lain dalam menjalin berkomunikasi dalam lingkup kehidupan sehari-hari.

Keterampilan berbicara merupakan keterampilan yang mekanistik. Semakin banyak berlatih, semakin dikuasai dan terampil seseorang dalam berbicara. Tidak ada orang yang langsung terampil berbicara tanpa melalui proses latihan (Kundharu Saddhono dan Slamet, 2012: 36).

Menurut Iskandarwassid \& Dadang Sunendar (2011: 241), keterampilan berbicara merupakan keterampilan mereproduksi arus sistem bunyi artikulasi untuk menyampaikan kehendak, kebutuhan perasaan, dan keinginan kepada orang lain. Dalam hal ini, kelengkapan alat ucap seseorang merupakan persyaratan alamiah yang memungkinkan untuk memproduksi suatu ragam yang luas bunyi artikulasi, tekanan, nada, kesenyapan, dan lagu bicara. Pendapat yang senada juga dikemukakan oleh Muammar (2008: 320) seperti berikut.

Keterampilan berbicara pada hakikatnya merupakan keterampilan mengucapkan bunyi-bunyi artikulasi atau mengucapkan kata-kata untuk menceritakan, mengekspresikan, menyatakan, menyampaikan pikiran, gagasan, dan perasaan kepada orang lain dengan kepercayaan diri untuk berbicara secara wajar, jujur, benar, dan bertanggung jawab, serta dengan menghilangkan masalah psikologis seperti rasa malu, rendah diri, ketegangan, berat lidah, dan lain-lain.

Berdasarkan sejumlah pengertian di atas, disimpulkan keterampilan berbicara merupakan keterampilan yang dimiliki oleh seseorang untuk menyampaikan kehendak, perasaan, ide maupun gagasan kepada orang lain secara lisan.

\section{Tujuan Berbicara}

Tujuan utama dari berbicara adalah untuk berkomunikasi. Agar dapat menyampaikan pikiran secara efektif, sebaiknya pembicara memahami makna segala sesuatu yang ingin dikomunikasikan (Henry Guntur Tarigan, 2008: 16). Kundharu Saddhono \& Slamet (2012: 36), mengungkapkan bahwa berbicara dapat dimanfaatkan untuk mengkomukasikan ide, perasaan, dan kemauan, serta untuk lebih menambahkan pengetahuan dan cakrawala pengetahuan.

Berbicara pada dasarnya mempunyai maksud umum yang ingin disampaikan. Ada tiga maksud umum dalam berbicara, yaitu: (a) memberitahu dan melaporkan (to inform), (b) menjamu dan menghibur (to entertain), dan (c) membujuk, mengajak, mendesak, serta meyakinkan (to persuade) (Henry Guntur Tarigan, 2008: 16-17).

Berdasarkan sejumlah tujuan yang dipaparkan di atas, dapat disimpulkan tujuan berbicara yaitu: untuk menginformasikan, menghibur, memberitahukan dan meyakinkan orang lain dalam rangka berkomunikasi untuk menambah pengetahuan dan cakrawala.

\section{Langkah-langkah Berbicara}

Berbicara merupakan sebuah rangkaian proses. Dalam berbicara terdapat langkah-langkah yang harus dikuasai dengan baik oleh seorang 
pembicara. Berikut ini merupakan langkah-langkah yang harus dikuasai oleh seorang pembicara yang baik yaitu:

1. memilih topik, minat pembicara, kemampuan berbicara, minat pendengar, kemampuan mendengar, waktu yang disediakan

2. memahami dan menguji topik, memahami

3. pendengar, situasi, latar belakang

4. pendengar, tingkat kemampuan, sarana

5. menyusun kerangka pembicaraan, pendahuluan, isi serta penutup (Kundharu Saddhono dan Slamet, 2012: 6).

\section{Faktor-faktor Penunjang Keefektifan Berbicara}

Kegiatan berbicara dipengaruhi oleh faktor-faktor yang menunjang keefktifan berbicara itu sendiri. Faktorfaktor ini terdiri dari dua macam, yaitu faktor kebahasaan dan faktor nonkebahasaan. Berikut merupakan perincian masing-masing aspek tersebut.

1. Faktor-faktor kebahasaan sebagai penunjang keefektifan berbicara, seperti berikut.

a. Ketepatan ucapan.

b. Penempatan tekanan, nada, sendi, dan durasi yang sesuai.

c. Pilihan kata (diksi).

d. Ketepatan sasaran pembicaraan.

2. Faktor-faktor nonkebahasaan sebagai penunjang keefektifan berbicara, seperti berikut.

a. Sikap yang wajar, tenang, dan tidak kaku.

b. Pandangan harus diarahkan kepada lawan berbicara.

c. Kesediaan menghargai pendapat orang lain.

d. Gerak-gerik dan mimik yang tepat.

e. Kenyaringan suara juga sangat menentukan. f. Kelancaran.

g. Relevansi atau penalaran (Maidar G. Arsjad \& Mukti, 1993: 17-22).

\section{Jenis Berbicara}

Berbicara mempunyai jenis-jenis yang berbeda. Secara garis besar, berbicara (speaking) dapat dibagi atas:

1. Berbicara di muka umum pada masyarakat (public speaking) yang mencakup empat jenis, yaitu:

a. berbicara dalam situasi-situasi yang bersifat memberitahukan atau melaporkan; yang bersifat informatif (informative speaking),

b. berbicara dalam situasi-situasi yang bersifat

c. kekeluargaan, persahabatan (fellowship speaking),

d. berbicara dalam situasi-situasi yang bersifat membujuk, mengajak, mendesak, dan meyakinkan (persuasive speaking), serta

e. berbicara dalam situasi-situasi yang bersifat merundingkan dengan tenang dan hati-hati (deliberative speaking).

2. Berbicara pada konferensi (conference speaking) yang meliputi:

a. Diskusi kelompok (group discussion), yang dapat dibedakan atas: (1) tidak resmi (informal), dan masih dapat diperinci lagi atas kelompok studi (study groups), kelompok pembuat kebijaksanaan (policy making groups), dan komik (2) resmi (formal), yang mencakup pula konferensi , diskusi panel, dan simposium .(b)prosedur parlementer (parliamentaryprocedure) debat (Henry Guntur Tarigan, 2008: 24-25). 
Berbicara terdiri atas berbicara formal dan informal. Berikut ini merupakan klasifikasi berbicara formal menurut Mudini Salamat Purba (2009: 5) yaitu: (1) diskusi, (2) ceramah, (3) pidato, (4) wawancara, dan (5) bercerita (dalam situasi formal). Sedangkan berbicara informal menurut Mudini Salamat Purba (2009: 5) terdiri atas: (1) bertukar pikiran, (2) percakapan, (3) penyampaian berita, (4) bertelepon, dan (5) memberi petunjuk.

\section{Aspek Penilaian Berbicara}

Penilaian dalam sebuah pembelajaran harus ditujukan pada tujuan pembelajaran itu sendiri. Penilaian adalah usaha untuk mengukur ketercapaian tujuan yang telah ditetapkan (Kundharu Saddhono \& Slamet, 2012: 2). Dalam mengevaluasi keterampilan berbicara seseorang, pada prinsipnya seorang guru harus memperhatikan lima faktor, yaitu sebagai berikut.

1. Apakah bunyi-bunyi tersendiri (vokal dan konsonan) diucapkan dengan tepat?

2. Apakah pola-pola intonasi, naik turunnya suara, serta tekanan suku kata, memuaskan?

3. Apakah ketetapan dan ketepatan ucpan mencerminkan bahwa sang pembicara tanpa referensi internal memahami bahasa yang digunakan?

4. Apakah kata-kata yang diucapkan itu dalam bentuk dan urutan xx yang tepat?

5. Sejauh manakah "kewajaran" atau "kelancaran" ataupun "ke-nativespeaker-an" yang tercermin bila seseorang berbicara? (Brooks dalam Henry Guntur Tarigan, 2008: 28)

Menurut Kundharu Saddhono \& Slamet (2012: 2), aspek yang dinilai pada keterampilan berbicara terdiri atas aspek kebahasaan dan nonkebahasaan.
Aspek kebahasaan terdiri atas; ucapan atau lafal, tekanan kata, nada dan irama, persendian, kosakata atau ungkapan, dan variasi kalimat atau struktur kalimat. Aspek nonkebahasaan terdiri atas; kelancaran, penguasaan materi, keberanian, keramahan, ketertiban, semangat, dan sikap.

Aspek-aspek yang dinilai dalam penilaian keterampilan berbicara secara umum dibedakan menjadi dua, yaitu: kebahasaan dan non kebahasaan (Ahmad Rofie uddin \& Darmiyati Zuhdi, 1998/1999: 244). Aspek kebahasaan tersebut meliputi: (1) tekanan, (2) ucapan, (3) nada dan irama, (4) persendian,(5)kosakata/ungkapan atau diksi, dan (6) struktur kalimat yang digunakan. Sedangkan, aspek nonkebahasaan meliputi: (1) kelancaran, (2) pengungkapan materi wicara, (3) keberanian, (4) keramahan, (5) ketertiban, (6) semangat, (7) sikap, dan (8) perhatian.

\section{Struktur Kalimat}

Kalimat adalah gabungan dari dua buah kata atau lebih yang menghasilkan suatu pengertian dan pola intonasi akhir. Kalimat dapat dibagi-bagi lagi berdasarkan jenis dan fungsinya .Dalam suatu kalimat terdiri dari beberapa unsur antara lain subyek, predikat, obyek ,pelengkap dan keterangan.Pengenalan struktur kalimat sangat penting dalam berbahasa. Pemilihan dan penempatan kata dalam kalimat mempunyai peran penting dalam pemaknaannya.

$$
\text { Menurut Penny UV (2007:4) }
$$

bahwa grammar adalah salah satu cara bahasa menggabungkan kata-kata atau cra pembentukan kalimat yang bermakna dalam kaitanya,bahas sebagai lat interaksi dalam kehidupa sehari-hari. Jack (2001:199-300) menyatakan bahwa pentingnya usaha memperluas bacaan atau memeliki kegemaran membaca.Membaca bkan saja 
mengubah pengetahuan tapi juga meningkatkan pembendaharaan kata dan bahasa Inggris (extensive reading).

\section{METODE PENELITIAN}

\begin{tabular}{lrr}
\multicolumn{1}{c}{ Metode yang digunakan dalam } \\
penelitian ini adalah metode \\
eksperimen.
\end{tabular} (2011:72) "Metode eksperimen adalah sebuah metode penelitian yang digunakan untuk mencari pengaruh perlakuan tertentu terhadap yang lain dalam kondisi terkendali." Metode ini merupakan satu-satunya metode penelitian yang menguji secara benar hipotesis yang menyangkut hubungan kausal (sebab akibat). Dalam penelitian eksperimen ini, peneliti melakukan pengukuran sebanyak satu kali yaitu sesudah perlakuan. Jenis penelitian ini adalah penelitian kuantitatif. Populasi terjangkau dalam penelitian ini adalah seluruhan siswa SMP Islam Azzuriyah Jatiasih Bekasi tahun ajarn 2016-2017 dengan jumlah keseluruhan 180 siswa.Peneliti mengambil sampel dalam penelitian ini sebanyak 60 siswa kelas VIII SMP Azzuriyah Jatiasih Bekasi.Peneliti membagi menjadi dua kelompok belajar siswa.Satu kelompok menjadi kelompok eksperimen yaitu diberikan metode pembelajaran think,pair and share. Kel ompok kontrol adalah kelompok yang mempunyai pengusaan struktur yang rendah dan pengusaan struktur yang tinggi.

Tabel 1.Desain Penelitian

\begin{tabular}{|lcc|}
\hline & \multicolumn{2}{l|}{ Metode Pembelajaran } \\
\cline { 2 - 3 } $\begin{array}{l}\text { Penguasaan } \\
\text { Struktur kalimat } \\
\text { Konvensional }\end{array}$ & & Metode TPS \\
& A1 & A2 \\
\hline Tinggi B1 & A1B1 & A2B1 \\
\hline Rendah B2 & A1B2 & A2B1 \\
\hline
\end{tabular}

Keterangan:

A1B1 : Model pemberian metode TPS dan penguasaan struktur kalimat yang tinggi

A2B1 : Model pemberian metode konvensional dan penguasaan struktur kalimat yang tinggi.

A1B2 : Model pemberian metode TPS dan Penguasaan struktur kalimat rendah

A2B1 : Model Pemberian metode konvensional dan penguasaan struktur kalimat yang rendah.

Jumlah Sampel adalah 60 orang yang dibagi kedalam 4 kelas penelitian,masing-masing kelas peelitian berjumlah 15 orang.Berikut pembagian kelas penelitiannya, 15 siswa diberikan metode think,pair and share ( tps ) dan penguasaan struktur kalimat yang tinggi,15 siswa diberikan metode tps dan penguasaan stuktur

kalimat yang rendah,15 siswa diberikan metode konvensional dan penguasaan struktur kalimat yang tinggi dan 15 siswa diberikan metode konvensional dan penguasaan struktur kalimat yang rendah.

\section{HASIL DAN PEMBAHASAN}

Tabel 2. Deskripsi Statistik

Descriptive Statistics

Dependent Variable: nilai
\begin{tabular}{|lc|c|c|c|}
\hline $\begin{array}{l}\text { Metode } \\
\text { TPS }\end{array}$ & $\begin{array}{l}\text { penguasaa } \\
\mathrm{n} \text { struktur }\end{array}$ & Mean & $\begin{array}{c}\text { Std. } \\
\text { Deviation }\end{array}$ & $\mathrm{N}$ \\
\hline
\end{tabular}




\begin{tabular}{|ll|l|l|l|}
\hline tinggi & tinggi & 75.4667 & 1.84649 & 15 \\
& rendah & 69.5333 & 6.08120 & 15 \\
& Total & 72.5000 & 5.34822 & 30 \\
\hline rendah & tinggi & 67.6667 & 4.01189 & 15 \\
& rendah & 64.8000 & 6.40535 & 15 \\
& Total & 66.2333 & 5.44998 & 30 \\
\hline Total & tinggi & 71.5667 & 5.01503 & 30 \\
& rendah & 67.1667 & 6.59197 & 30 \\
& Total & 69.3667 & 6.21634 & 60 \\
\hline
\end{tabular}

Tabel 2. merupakan ukuran statistik deskriptif pemakaian metode TPS ( think,pair and share ). Jumlah anak yang mendapat nilai tinggi pada pemakaian TPS sebanyak 15 dengan rata-rata kemampuan keterampilan berbicara sebesar 75.4667, sedangkan siswa yang memperoleh nilai rendah rata-rata sebesar 69.5333. Jumlah anak yang mendapat nilai katagori rendah pada pemakaian TPS sebanyak 15 dengan rata-rata kemampuan keterampilan berbicara sebesar 67.6667, sedangkan siswa yang memperoleh nilai rendah rata-rata sebesar 64.8000.

Pengaruh Metode Think, Pair, And Share dan Penguasaan Struktur Kalimat Terhadap Keterampilan Berbicara Bahasa Indonesia

Tabel di bawah ini menunjukkan hasil dari uji Anova dua jalur.

Tabel.3 .Uji Anova Dua Jalur Tests of Between-Subjects Effects

Dependent Variable: nilai

\begin{tabular}{|l|r|r|r|r|r|}
\hline Source & $\begin{array}{r}\text { Type III } \\
\text { Sum of } \\
\text { Squares }\end{array}$ & df & $\begin{array}{c}\text { Mean } \\
\text { Square }\end{array}$ & \multicolumn{1}{c|}{ F } & Sig. \\
\hline Corrected Model & $\begin{array}{r}914.733^{2} \\
288704.0\end{array}$ & 3 & 304.911 & 12.507 & .000 \\
Intercept & 67 & 1 & 288704.0 & 11842. & .000 \\
metode_tps & 589.067 & 1 & 589.067 & 24.163 & .000 \\
penguasaan_stru & 290.400 & 1 & 290.400 & 11.912 & .001 \\
ktur & & & & & \\
metode_tps \\
penguasaan_stru \\
ktur & 35.267 & 1 & 35.267 & 1.447 & .234 \\
Error & 1365.200 & 56 & 24.379 & & \\
Total & 290984.0 & 60 & & & \\
Corrected Total & 2279.933 & 59 & & & \\
\hline
\end{tabular}

a. R Squared $=.401$ (Adjusted R Squared $=.369$ )

Pada corrected model, dapat dijelaskan bahwa semua variable independen (metode TPS dan penguasaan struktur kalimat) secara bersama-sama terhadap variable dependent (keterampilan berbicara). Nilai sig. sebesar 0.000 ,berarti sig. <
0.05 (alfa $)=$ signifikan, berarti nilai model valid. Nilai R Squared sebesar 0.401 , terdapat pengaruh sebesar 40.1 $\%$ (tingkat sedang) antara semua variabel bebas terhadap variabel terikat. 
Pada data tabel 3 pada kolom metode tps dan penguasaan struktur kalimat nilai Sig. sebesar 0.234 , hal ini menunjukan bahwa nilai Sig. $>0.05$ (alfa) $=$ tidak signifikan.Dapat disimpulkan bahwa pengaruh metode TPS dan penguasaan struktur kalimat secara bersama-sama terhadap keterampilan berbicara Bahasa Indonesia tidak berpengaruh signifikan.

Metode TPS merupakan model belajar kooperatif yang dapat digunakan dikelas. Penguasaan struktur yang baik dapat mempengaruhi kemampuan berbicara.Secara teoritis dapat dikatakan semakin baik metode TPS diterapkan dengan diikuti kemampuan pemahaman struktur, maka semakin baik pula keterampilan berbicara yang akan didapat siswa.

Dari tabel 3 dapat disimpulkan bahwa tidak terdapat terdapat pengaruh metode TPS dan penguasaan struktur terhadap keterampilan berbicara .

Pengaruh Metode Think, Pair And Share Terhadap Keterampilan Berbicara Bahasa Indonesia.

Berdasarkan tabel 3 diatas dapat diperoleh untuk nilai sig. metode tps sebesar 0.000 ,berarti nilai sig. $<0.05$ ( alfa ),sehingga dapat dikatakan signifikan.Berarti metode tps berpengaruh terhadap keterampilan berbicara.Semakin baik penerapan metode tps maka keterampilan berbicara akan lebih meningkat. Pemberian metode yang berkesinambungan akan turut meningkatkan keterampilan berbicara siswa.

\section{Pengaruh Penguasaan Struktur} Kalimat Terhadap Keterampilan Berbicara Bahasa Indonesia.

Berdasarkan tabel 3 diatas dapat diperoleh nilai sig. penguasaan struktur sebesar 0.000 ,berarti nilai sig. $<0.05$ (alfa ),sehingga dapat dikatakan
tsignifikan.Berarti penguasaan struktur kalimat berpengaruh signifikan terhadap keterampilan berbicara. Penguasaan struktur kalimat yang baik akan membantu dalam meningkatkan keterampilan berbicara.

\section{SIMPULAN}

1. Tidak terdapat pengaruh yang signifikan metode think,pair and share dan penguasaan struktur kalimat secara bersama-sama terhadap keterampilan berbicara Bahasa Indonesia.

2. Terdapat pengaruh penguasaan struktur kalimat terhadap keterampilan berbicara Bahasa Indonesia.

3. Terdapat pengaruh yang signifikan metode think,pair and share terhadap keterampilan berbicara Bahasa Indonesia.

\section{DAFTAR PUSTAKA}

Jack C Richard.2002.Methodology In Language Teaching .Cambridge University Press

M.Thobroni dan A Mustofa, 2013 Belajar dan Pembelajaran, Yogyakarta, Ar-ruzz Media Penny UV.2006. A course in Language Teaching.Cambridge University Press.

Purba Salamat Mudini, Jakarta, Pembelajaran Berbicara, Modul Suplemen KKG bermutu (on line) http:id.scribb.com

Rofi'uddin Akhmad dan Darmiyati Zuhud. 2008. Pendidikan Bahasa dan Sastra Indonesia di kelas tinggi.Depdikbud Jakarta. 
Sadhono,K dan St.Y.Slamet, 2012, Meningkatkan Keterampilan Berbahasa Indonesia (teori dan aplikasi ),Bandung.Karya Putra

Trianto, 2010, Mendesain Model Pembelajaran Inovatif Proresif, Jakarta,Kencana media
Tarigan Guntur Henry, 2008, Membaca sebagai Suatu Keterampilan Berbahasa,Bandung Angkasa.

W. Solchan, dkk, 2009. Materi pokok Pendidikan Bahasa Indonesia di SD;1-12 Pdk Jakarta UT Depdikbud 